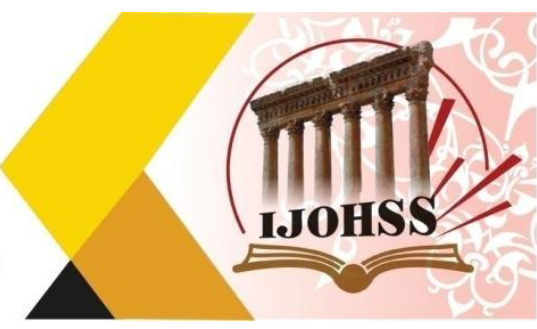

\title{
The Idea of Fear as Reflected in Shaw's Saint Joan
}

\author{
Assist. Lect. Khawla Muzahim Ali \\ College of Arts \\ Al-Iraqia University \\ Iraq
}

\begin{abstract}
One of the major themes that Shaw explores in his works is the concept of fear and terror. Fear of revolution or reformation takes precedence over all other fears in his plays .This paper shows how Shaw had tackled this recurring idea of fear from change, reformation and revolution. It reflects Shaw's philosophy that the essence of our changing human world is revolution and reformation. As a result, there are antirevolutionary forces that are afraid of such revolutionary figures. For the sake of truth and social reformation, reformists do their best and even risk their lives. Joan of Arc, a historical heroine, is used by Shaw as a symbol for reformation and revolution. Those who dread such people, on the other hand, do everything they can to prevent people from using their sacred right to revolt against tyranny and injustice. The paper focuses on Saint Joan as Shaw's best work that deals with the fear of reformation.
\end{abstract}

Keywords: fear, terror, Saint Joan. 


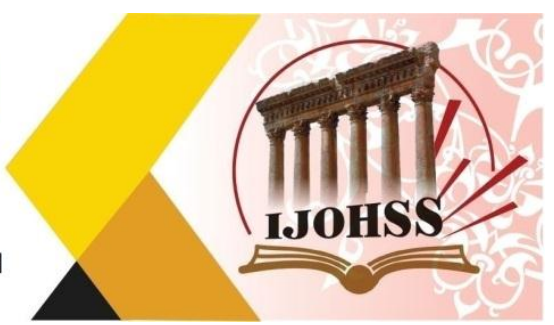

\section{Introduction}

The idea of fear is one of the important themes that Shaw reflects in his works. The fear from revolution or reformation towers above all kinds of fear reflected in his plays. Revolution

and reformation are the essence of our changing human world. And for this reason there are also anti-reformation forces that fear from such revolutionary people. The reformists do their best and sometimes sacrifice their life for the sake of truth and for the social reformation. On the other hand, those who fear from such people do their best to stop that sacred right of revolting against tyranny and injustice. The best of Shaw's works that talks about the fear from reformation is Saint Joan. In it Shaw takes the historical figure of Joan of Arc as a symbol for the reformation and revolution. Saint Joan (1923) is one of the most outstanding dramas of the twentieth century. For it, Shaw received the 1925 Nobel Prize in literature. He wrote it shortly after the Roman Catholic Church had canonized Joan of Arc in 1920.This play is a dramatization based on the records of her trial made public by the church in 1920 . Shaw through this play introduces his theory of Life Force or, sometimes is called, Creative Evolution. It gives an analysis of his view about transformational agents exemplified by saint Joan or any other martyrs. He gives a deep description of the fear that is rooted in the western world from religious reformation or even Islam. This play is not a historical dramatization of an event that is no more. But it is a dramatization of a sacred phenomenon that has been present throughout the history of humanity. It is the revolution that springs from free and brave men. Shaw best defines the fear from revolution through this play. He describes its causes and its results which can be seen in any time and place in our human world. But before discussing how Shaw reflects the idea of fear in this play, it is more important to know something about Joan of Arc and Shaw the revolutionary writer.

\section{Saint Joan, The Maid, the leader, and the Martyr}

Joan of Arc is the French saint and national heroine who united the nation at a critical hour and decisively turned the Hundred Years' War in France's favor ${ }^{1}$. She is known by different names such as The Maid of Orleans, La Pucelle, Jeanne (Jehanned'Arc). Her exploits are thought by many to have changed the course of European history. She is one of most famous and best document of all historical figures. Joan of Arc was born on the dawn of the Feast of the Epiphany January 6th, in 1412 to Jacques and Isabelle Arc in the village of Domre-my, on the border of Champagne and Lorraine ${ }^{2}$. Her birth seemed as if announced a new type of dawn to

\footnotetext{
1 Joan Bell Henneman, "Hundred Year's War", Encarta Encyclopedia,Microsoft corporation, 2004.

${ }^{2}$ www.joan-of-arc.org/joanofarc-footnote-113.html.
} 


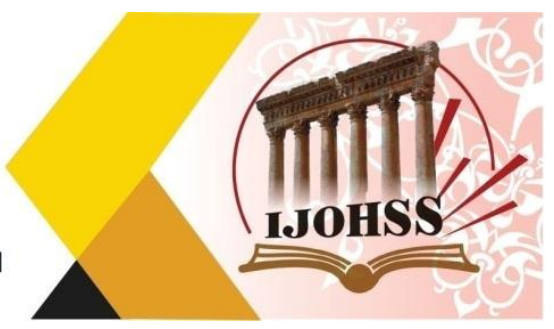

Europe and to Christianity. The events in France during the years of The time she was born there was a shaky truce between France and England. But then a civil war erupted between two factions of the French Royal family which would allow the English to re-invade France. The first faction called the "Orleanists", was led by Count Bernard VII of Armagnac and Duke Charles of Orleans; the second faction, their rivals, known as the "Burgundians", were led by Duke John-the-Fearless of Burgundy. Thus, the French were divided into warring parties and this helped king Henry V invade France in August $1415^{3}$. "From girlhood she had a deep religious faith, and as she grew up and began to take an interest in things she sorrowed more and more for the afflictions of her country, much of which was over-run by the English."

It was around 1424, when she was twelve, that Joan said she began to have vision of Saint Catherine, Margaret5 and St. Michael the Archangel ${ }^{6}$. In 1428 the situation became critical, as the English prepare to attack the city of Orleans and thereby gain control over the crucial valley of the Loire River, the northern side of Charles' dwindling domain. It was at this time, as Joan later said, that she finally obeyed the orders of her saints to lead an army against the English and Burgundians. And "she declared she had seen visions and heard voices calling upon her to take up arms for king Charles VII, to raise the siege of Orleans and to lead him to Rheim to be crowned." She explained this mission as that God had taken pity on the French for the suffering they had endured. "She was dismayed by the hardships her people had suffered in the war and sought an end to the conflict.",

Being the last major city defending the heart of Charles territory, Orleans was placed under the siege of an English army led by the Earl of Salisbury. This was a difficult and hopeless situation facing Charles government. Joan was finally granted Baudricourt's 9 permission after her third attempt, to go with an escort to speak with Charles. Baudricourt arranged for an armed escort to bring Joan to Chinon. He escorts her in male clothing, as a disguise in case the group was captured and thus the enemy would not identify her as a woman. The eyewitnesses said she always kept this clothing on and laced tightly when camped in the fields with soldiers, for safety and modesty's sake. She would call herself "La Pucelle" (The Maiden or Virgin),

\footnotetext{
${ }^{3}$ ibid

4 Norman T.Carrington,Brodie's Notes on Shaw's Saint Joan,(London:Pan Book Ltd,1976),p16

${ }^{5}$ Two early Christian martyrs.

${ }^{6}$ identified in the Bible as the commander of Heaven's armies who led the war against Satan.

${ }^{7}$ ibid.p 16.

${ }^{8}$ William James Adams, "France”,Encarta Encyclopedia,Microsoft Corporation 2004.

${ }^{9}$ A military commander.
} 


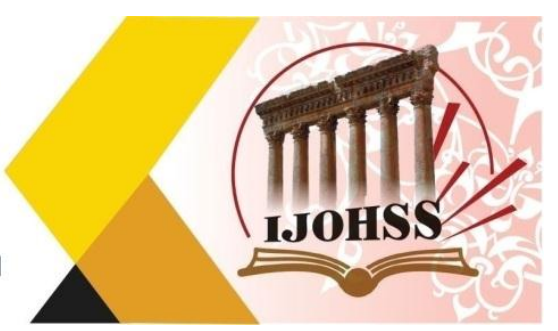

explaining that she had promised her saints to keep her virginity for as it pleases God. It is by this nickname that she is usually described in the documents ${ }^{10}$. Eventually, when she was brought into Charles's presence and his counselors at Chinon on $23^{\text {rd }}$ February 1429, she presented herself before him with great humility and simplicity, a poor shepherd girl. She said to him: "Most illustrious Lord Dauphin (i.e., heir to the throne), I have come and am sent in the name of God to bring aid to yourself and to the kingdom" ". They were convinced of her and they gave her their approval of the command of an army to march to the aid of Dunois in the relief of Orleans.

Historical accounts indicate that she convinced Charles to take her seriously and to grant her the leadership of an army by telling him about a private prayer he had made the previous November $1^{\text {st }}$. In it he had asked God to aid him in his cause if he was the rightful heir to the throne. And to punish himself alone rather than his people if his sins were responsible for their suffering and for his failure to liberate his country $^{12}$. After hearing this Charles was convinced because nobody knew of this prayer except himself and God. Moreover, he made her be examined by a group of the theologians in order to test her orthodoxy ${ }^{13}$. She succeeded in this test and she earned a reputation as "another saint Catherine come down to earth"1 . The French became inclined to believe her and put their trust in her because she fitted to the old legend about the maid who will save them. "The citizens of France knew of an old legend about a maid that would come and save France in their time of need. It was communicated to the people that a young maid would come from Lorraine Valley"15. Joan came from Domre'my which rests in the Lorraine Valley. Consequently, their trust in her grew. She then sent letters to the English commanders in Orleans telling them to go back to England. She began those letters with "Jesus- Mary" slogan she also informed those commanders that son of Saint Mary (i.e. Jesus Christ) supports Charles VII's claim to the throne ${ }^{16}$. So in male dress and a suit of white armour, mounted on a charger, she bore the sword and the sacred banner, as the signal of victory; at the head of army of four thousand men and joined forces with Dunois. She led this army against the English besieging Orleans. This expedition successfully broke the siege. The maid followed this victory with another over the English at

\footnotetext{
${ }^{10}$ www.joan-of-arc/joanofarc/biography.

11 Ibid.

12 Brodies Notes 16.

13 This was an arrangement which was occasionally given to religious visionaries during the medieval period.

${ }^{14}$ www.joan-of-arc/joanofarc/Biography.

${ }^{15}$ Jeremy Roberts. Saint Joan of Arc ,(Minneapolis: Lerner Publication Co.2000),p25.

${ }^{16}$ www.joan-of-arc.org/joanofarc/Biography.
} 


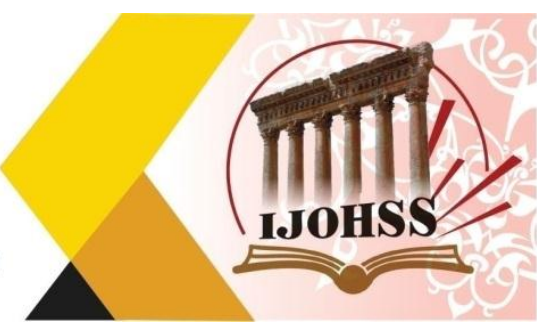

Patay, and then led Charles to Reims, deep in the enemy held territory, where he was crowned king of France ${ }^{17}$.

Joan acted as a figurehead rather than a field commander. She succeeded because of her military prowess and the support of her fellow citizens whom she united so that they worked together to triumph together: "Joan of Arc, became the hero France needed to save their desperate country she led the French army to a glorious victory at Orleans. Joan's brilliant leadership during the Battle of Orleans boosted her countrymen's self-esteem, enabling them to end the hundred years' war in their favor" ${ }^{18}$. Napoleon Bonaparte even noted that Joan helped to revitalize the French during important battles: "The illustrious Joan of Arc proved that there is no miracle which French genius cannot work in circumstances where national independence is threatened" $" 19$. She instilled loyalty within the French to unite France under a French king. They steadfastly supported her and followed her field decisions and guidance. "She stirred the sense of nationalist within the French and thus she became the heroine of the Hundred Years' war and the inspiration of many people to come" 20 . Through her self-confidence, determination, and courage, she had the ability to get soldiers and captains to listen to her and do as she wanted them to do concerning military tactics." 21 Her leadership provided spirit and moral more than military prowess.

Even after Charles's coronation, she continued to lead the French troops. In September 1429, Joan unsuccessfully besieged Paris. But she failed and was wounded. After she recovered she went back to the field again with her French armies. In 25th May, 1430, when she was with some men going to Compiegne, she was captured by the Burgundians and sold to the English who were eager to destroy her influence by putting her to death. Charles VII made no effort to secure her freedom. Then the English turned her over to a court of Inquisition in Rouen at the instigation of the Bishop of Beauvais, who was a tool of the English. After a long and disgraceful trial, she was tried for heresy, witchcraft and disobedience to the Church before Pierre Cauchon and other French clerics who supported the English ${ }^{22}$ "Probably her most serious crime was the claim of direct inspiration from God"23. And the court considered the refusal to accept the church hierarchy as heresy.

\footnotetext{
${ }^{17}$ Brodies Notes,p17.

${ }^{18}$ Joan Arnold, "Saint Joan of Arc, A modern Day Hero For All”,www.stjoan-centre.com

${ }^{19}$ Christopher Russell."The Creativity of Joan of Arc",www.therussell.net/papers/joan.

${ }^{20}$ Ibid.

${ }^{21}$ Ibid.
}

${ }^{22}$ Edward luic Smith. Joan Of Arc

${ }_{23}$ "Joan of Arc" The Columbia Encyclopedia, $6^{\text {th }}$ edition,2001,www.bartleby.com/65/jo/joannabib.html. 


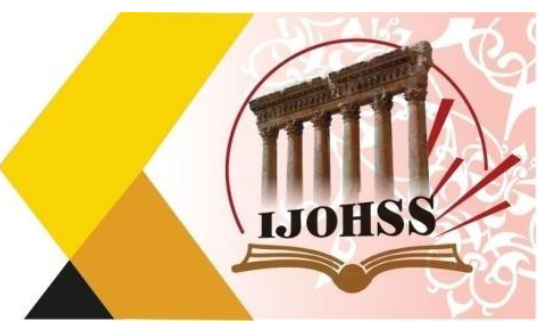

"Those whom she led to victory believed that she was inspired of God, and the English, not denying her inspiration believed that it was of the Devil."24 On the charge of a relapsed heretic, she was brought to the stake and burnt on 30th May 1431.

She was only nineteen but she accomplished her holy mission successfully. She showed a great bravery and heroism during her trial and she faced death with unshaken courage. After that her ashes were thrown into the Seine as a remark of disgrace. But historical records narrate that although she was burned and turned to ashes, yet her heart remained safe. Her family did not give up and kept on pressing for a rehabilitation trial. After twenty-five years in 1456, at a court specially constituted by Pope Calixtus III, Joan was pronounced innocent. Since then she has been considered one of the most famous French national heroines ${ }^{25}$. And within the 20th century, she has been exalted to sainthood and then was declared Venerable in 1904. She was beatified in 1909 and canonized as a full saint in the Catholic calendar by Pope Benedict XV in 192026. The writer Louis Kossuth says of her: "Consider the unique and imposing distinction that since the writing of human history began, Joan of Arc is the only person, of either sex, who has ever held supreme command of the military forces of a nation at the age of seventeen.",27

Although she was killed hundreds years ago, yet still her story and martyrdom throbs in the pulse of poets, writers and generation to come. And as critic A.C. Ward says:

The story of Joan of Arc, the French girl who won back her country from the English invaders is one of the world's greatest stories. Though it all happened in France more than five hundred years ago it is not simply an old story. It will continue to be new and important until there are no longer men who set out to conquer and rule over others ${ }^{28}$

\section{Shaw The Revolutionist}

George Bernard Shaw is one of the important and most provocative controversialists of the first half of the twentieth century ${ }^{29}$. He was born in Dublin on

\footnotetext{
${ }^{24}$ Charles W. Colby,ed."Medieval Sourcebook: The Trial of Joan of Arc,1431"Selections from the sources of English History,55BC-AD 1832(London:Longman,Green,1920),p 113.

${ }^{25}$ www.joan-of-arc.org/joanofarc/Biograhy.

${ }^{26}$ Ibid.

${ }^{27}$ Louis Kossuth, "Legends of Joan of Arc",www.thedividingnation.com/comlegendsof-JoanofArc.

${ }^{28}$ Encarta Encyclopedia.

${ }^{29}$ Stanley Weintraub, "George Bernard Shaw", Encarta Encyclopedia,Microsoft Corporation 2004.
} 


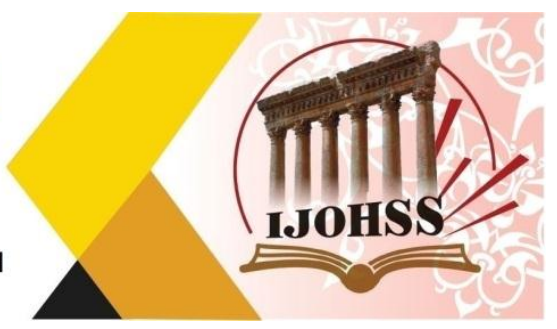

26th July 1856, in a very ordinary home. From his childhood he had his own love of reading. He read anything and everything that came his way ${ }^{30}$. He studied Karl Marx and made himself prominent in the early Socialist movement. In 1884 he became one of the founders of the Fabian Society. All his life he called himself a Socialist ${ }^{31}$. Shaw made many contributions to the modern theatre. He was revolutionary in the themes of his plays and in the style he used to convey his ideas. The rules to construct his plays were his own ${ }^{32}$. "Shaw was fascinated by ideas of all kinds, and he use his outstanding dramatic skill to publicize all sort of notions- from the importance of the science of Phonetics (Pygmalion) to the "Protestantism' of Joan of Arc."33 The Edwardian era (1892-1913) was rich in revolutionary ideas. A new theatrical renaissance was ushered in with the publication of Shaw's Widowers House (1892) under the influence of the Norwegian dramatist Henrik Ibsen. Shaw was influenced by Ibsen's works. He defended Ibsen against the attacks of the critics. He praised Ibsen's way of revolutionizing drama stating that this was the way the new drama should go. It should concentrate on ideas, and it should focus on inner life rather than on external aspects of life. This influence by Ibsen made Shaw follow his notions of new drama, and put them into practice ${ }^{34}$.

It was the intellectual drama that Shaw and his contemporaries were interested to write. They used the theatre as a social force by raising questions as to the sanity of the conventions of the well- made plays. Shaw intended to use the theatre for propaganda. To him the man who believed in art for art's sake is a fool." $35 \mathrm{He}$ considered art as too great to be understood in such doctrine. "The life and spirit of art, that glorious thing in us which makes us feel the beautiful, the true and the good, is not propaganda, but may be it is the spirit which prompts that propaganda."36 Shaw explained the theme of his plays in the Prefaces. In all of Shaw's plays, the drive of a thesis argued in the Preface is the mainspring of the play. Shaw himself acknowledges this and declares that all his plays have a message for mankind:

My chief contribution to my generation has been my great success in stimulating the thoughts of men and women. With each new play I have brought a message to mankind. Indeed,

\footnotetext{
${ }^{30}$ Norman T. Carrington,Brodie's Notes on Shaw's Saint Joan 8.

${ }^{31}$ Ibid, P 8.

32 John Burgess Wilson. Survey of English Literature(London:Longman,Green and Co Ltd,1969),P 251.

${ }^{33}$ Ibid, P 261.

${ }^{34}$ Ibid,P 259.

${ }^{35}$ Brodies Notes on Saint Joan,P 8.

${ }^{36}$ Ibid ,P 8.
} 


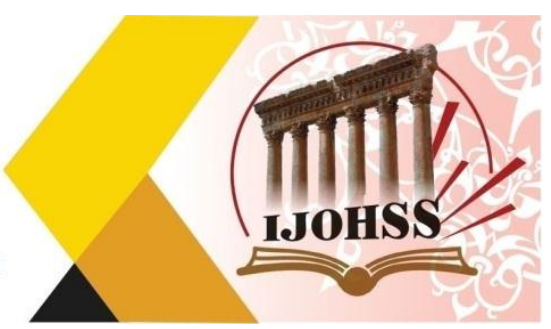

in the realm of ideas I may be called the messenger boy of my time ... each play is a testament of my convictions ... Saint Joan: on heroism and saintliness 37 .

Shaw has declared the theme of Saint Joan in the preface, in which he calls "a sober essay on the bare facts" ${ }^{\prime 38}$. He is the only modern dramatist who started to write plays which were read and not acted. All his plays are problem plays and are read as much as for the prefaces as for the plays themselves ${ }^{39}$. It is recognized that as a means of expanding Shaw's influence was to print his plays with detailed introductions and stage directions. He articulated his views by fusing two genres, the polemical essay with the drama ${ }^{40}$.

The preface to Saint Joan gives an accurate account of Joan of Arc's martyrdom and her persecutors devoid of sentimentality, romanticism, or slander. He intends to "get rid of the mud that is being thrown at her judges, and the whitewash which disfigures her. ${ }^{, 41}$ For Shaw Joan emerges from history as neither angel nor devil, but as a genius with an active imagination. The Inquisitor rises from the mist of cruelty, and appears as compassionate men who operate only within the scope of their medieval world- view. In fact, Shaw did not take the side of any of his characters. He lets us see not only her point of view but also her opponent's reasons for persecuting and destroying her. Both sides declared their own evidences and thus Shaw leaves the reader to conclude his/ her own judgment. To do this, Shaw employs the methods and techniques of his artistic imagination and not that of a historian, who gives only facts and neglects the unrecorded motives and evidences that lie behind the facts. 42

\section{Life Force}

In Shaw's earlier plays the theme generally is about economic affairs, but in the later plays, especially Saint Joan, the focus is on a religious one. Shaw's constant beliefs on anything are difficult to state, because whatever statement is made can be

\footnotetext{
${ }^{37}$ Ibid,P 21.

${ }^{38}$ Ibid,P 22.

${ }^{39}$ Stanley Weintraub.

40 "The Playwright in spite of Himself:George Bernard Shaw,Man,Superman,and Vegetarian?"

File://A:IThe Playwright in spite of Himself.Html(11/19/04).

${ }^{41}$ Shaw, "Preface", Saint Joan,(London:Penguin Books, 1961),P 10.

42 P.S.Avasthi \& V. K Maheshwari,eds.Saint Joan,(New Delhi:Lakshmi narain Agarwal,n.d.),P 102.
} 


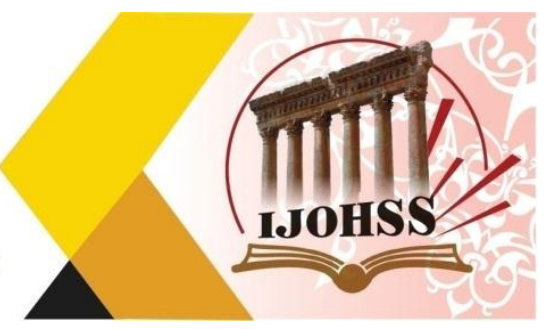

contradicted somewhere in his work.43His attitude to religion is that of a rationalist. $\mathrm{He}$ understood and interpreted Christianity rationally. He propounded his own religion of Creative Evolution44. Thus he replaced the orthodox and conventional Christianity with his modern scientific religion of Creative Evolution. Show says that it had "newly arisen from the ashes of pseudo- Christianity, of mere skepticism, and the soulless affirmations and blind negations of the mechanists and the NeoDarwinians." 45 There is not much difference between Darwin's theory of evolution and Shaw's theory. Darwin approached the law of evolution from the physical side of nature, and his law covers not only human beings but all animals. Whereas Shaw's law of Creative Evolution can be applied to human beings only ${ }^{46}$. Through this theory, he focuses upon glorifying intellectuality. "Shaw's theory of life force exposes a fantastic, imaginative and semi- mystical strain in Shaw's personality." really interested him was man's social welfare and as a solution to its perplexities, he suggested the life Force ${ }^{48}$. Show said: "I say that life force is God." This saying is best discussed by St. John Ervin's summary of Shaw's religious point of view:

God, or the life force, is an Imperfect power striving to become Perfect... The whole of time has been occupied by God in experiments with instruments invented to help Him in His attempts to perfect Himself. God created a new instrument, Man, who is still on probation. Shaw warns the world that if we, too, fail to achieve God's purpose, He will become impatient and scrap mankind as He scrapped the mammoth beasts. ${ }^{49}$

What appeals strongly to Shaw is the idea of being an active partner in establishing the kingdom of God. This is one of the main pillars of Shaw's new religion or life Force theory. This is further interpreted by the critic Maurice Calbourne in his book The Real Bernard Shaw as:

\footnotetext{
${ }^{43}$ Norman T. Carrington,Brodie's Notes on Saint Joan,(London:Pan Books Ltd,1976),P 10

${ }^{44}$ Ibid ,P 10.

${ }^{45}$ Shaw, "Preface",Back To Methuselah,(New Delhi:Lakswari Norain Agarwal,n.d.),P 27.

${ }^{46}$ Ibid ,P 28

${ }^{47}$ Ibid,P 29.

${ }^{48}$ Ibid,P 29.

${ }^{49}$ Carrington,Brodie's Notes,P 10.
} 


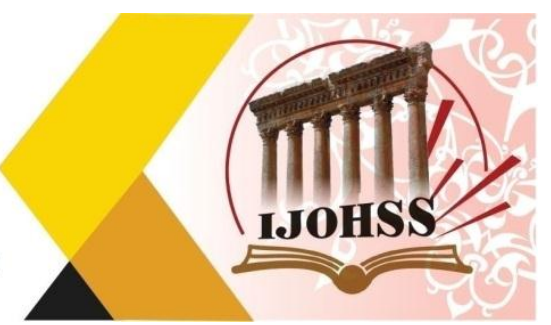

For Shaw the most acceptable way of establishing the kingdom of God is to labor with God (or Whatever you like to call Him- Life Force, etc.) and help to build it, instead of dawdling in the courts of ritualistic praise and indulging the emotions... Thus, the kingdom of God becomes a co- operative enterprise conducted on modern lines, with the workers as part-owners. The kingdom of God is theirs as well as God's50.

Behind Shaw's theory of Creative Evolution there is his faith in man's power for progress. "By virtue of his intellectual and spiritual force man must evolve to a higher and higher state of living irrespective of God's will or permission." 51 Shaw calls this spiritual power for progress in the universe as Life Force. In Saint Joan, Shaw practiced his new religion. This play is an expression of his theory of Life Force. Critic Maurice Valency identifies Joan as a symbol of progress dialectictically opposed to the preservers of order, Warwick and Cauchon. They represent the equal and opposite force of reaction to her action. And as Valency says: "the play in these terms fitted admirably into Shaw's philosophic scheme... Joan, in her sacred aspect is... a spectacular realization of the Life Force, a genius precariously balanced on the threshold of the future, and therefore especially vulnerable to the forces of reaction" $" 52$.

Shaw describes the Life Force as an evolutionary appetite, which uses individuals like Joan to effect social change ${ }^{53}$. The forces of stasis, the feudalists and the Catholic priests in Saint Joan, are never ready to accept the evaluation of civilization, so they must destroy the revolutionary. They all persecuted Joan because in Shaw's view, "all evolution in thought and conduct must at first appear as heresy and misconduct" ". Shaw as if was saying that martyrs like Joan gave their life for the sake of life's progress. They thus renew life by allowing the change to occur. He considers the law of change as the law of God. Shaw further explains this:

Though all society is founded on intolerance, all improvement is founded on tolerance, or the recognition of the fact that

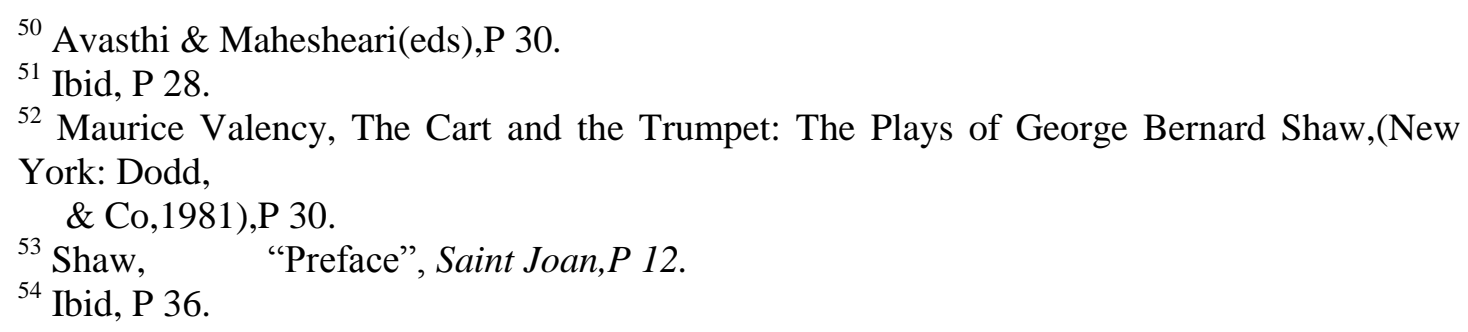




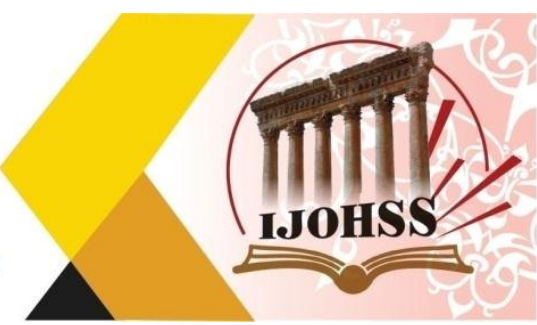

the law of evolution is Ibsen's law of change. And as the law of God in any sense of the word which can now command a faith proof against science is a law of evolution, it follows that the law of God is a law of change, and that when the Churches set themselves against change as such, they are setting themselves against the law of $\operatorname{God}^{55}$.

Thus Joan's martyrdom is explained as one agent of Life force. Consequently, "Life Force is the sustained will to progress, to rise on the hierarchal ladder of life." And Joan as a saint and as a martyr represents the power of this progress.

\section{Saint Joan the Shavian Tragedy}

Saint Joan is considered by many critics to be Shaw's masterpiece. "It strikes every chord from happy laughter to poignant tragedy." represents one of the new heroines in English drama. In almost all of Shaw's plays, he treats the new woman as an isolated phenomenon, exclusively Shavian. The emergence of the new woman was a noteworthy feature in the late Victorian and twentieth century drama. For the first time significant stage roles were created for women. New women in drama eschewed their traditional roles of submissiveness and seized the roles of the protagonist. The American critic, Eric Bentley describes Shaw's portrayal of Joan of Arc as the culmination of his girl heroines. "Saint Joan is an attempt at several kinds of synthesis. In it Shaw unites the practical and the ideal and carries as far as he can take it the spirituality of the girl heroines." 58 To Shaw Saint Joan is a good example of his Life Force theory. She is a vehicle for him to present a woman in her active, true roles as a mover of the evolutionary process. And as Bently points out, if history had not produced Saint Joan, Shaw would have had to invent her 59 . Joan's story is a Shavian tragedy, not because so young and pious a girl was burned at the stake, but because she was burned by learned and pious men. Or as Shaw says: "The tragedy of such murders is that they are not committed by murderers. They are judicial murders, pious murders; and this contradiction at once brings an element of comedy into the tragedy; the angels may weep at the murder, but the gods laugh at the murderers." 60

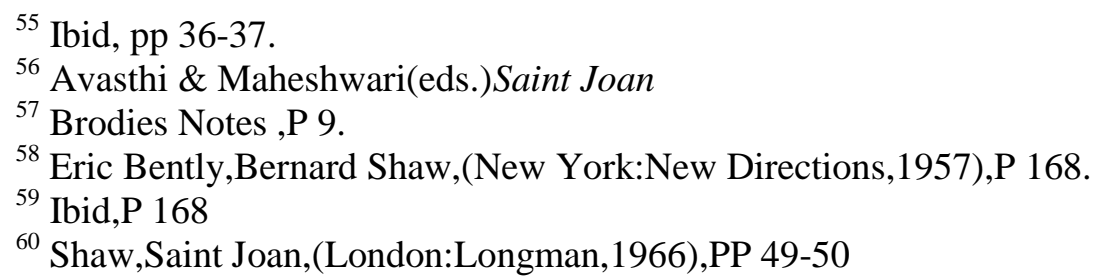




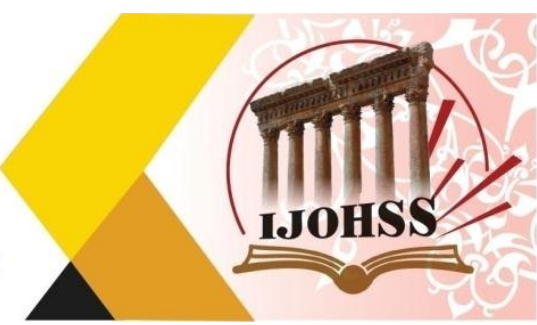

The Church Militant becomes a sort of tragic hero because of Joan's tragic flaws. Her influence upon people, her arrogance, frankness, and pride threaten to disorder the tradition and dominion of the church and state. Saint Joan is fit to be an Aristotelian hero by Shaw's view but critic Luis L. Martz considers her as Shavian:

Joan's apparent resemblance to the Aristotelian hero: her extreme self- confidence, her brashness, her appearance of rash impetuosity- all this becomes in the end a piece of Shavian irony, for her only real error in the play the one point where her superb self- confidence breaks down in the panic recantation. And so the hubris is not Joan's but Every- man's. The characters who accuse Joan of pride and error are in those accusations convicting themselves of the self- righteousness and the errors of human certitude. It is true that the suffering that results from this pride and error remains in Shaw's play rather theoretical and remote; and yet we feel it in some degree: in the pallor and anguish of Joan as she resists the temptation to doubt her voices, in the rather unconvincing screams at Stogumber at the close, and in the quiet, controlled sympathy of Ladvenu ${ }^{61}$.

The critic Maurice Vallency calls Saint Joan a thesis play, which demonstrates a conflict of ideas. The characters symbolize abstract conceptions of religion and politics subject to unavoidable shift in historical perspective, which change the nature of their authority. The difference between Joan and her persecutors is mainly a matter of perception ${ }^{63}$. While critic David Daiches does not consider this play as a tragedy but as comedy:

Saint Joan is in many ways a brilliant play; it not a tragedy, but a comedy with one tragic scene, and the comedy lies in the way in which Shaw interprets his historical characters in the light of his own modern understanding and preoccupations He never really comes to terms with the miraculous in this play: he uses it for comic effect and to implement his view

\footnotetext{
${ }^{61}$ Louis L. Martz, "The Saint as Tragic Hero", Tragic Themes in Western Literature, Cleanth Brook,(ed) (New Haven: Yale University Press,1960)P 160.

${ }^{63}$ Maurice Valency, The Cart and the Trumpet: The Plays of George Bernard Shaw, (New York Oxford UP.,1973),P 384.
} 
العدد (28) ديسمبر 2021

Volume (28) December 2021

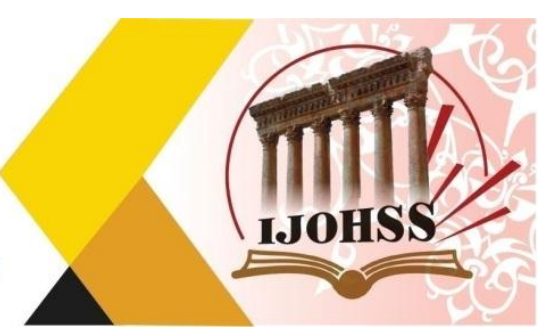

$e^{64}$

Each of the six scenes of Saint Joan explores the differences between the character's perceptions of miracle and coincidence, faith and reason, death and martyrdom, and divine inspiration and demonic possession." As he and Ibsen had to write, within the conventions of the modern realistic theatre" the concept of miracle and sainthood approachable to modern reader. This is further explained by Martz:

That on this stage facts matter- or at least the appearance of facts- and in this need for dramatic realism lies the basic justifications for Shaw's elaborately argued presentation of Joan as a Protestant and Nationalist martyr killed by the combined institutional forces of feudalism and the Church. Through the body of the play, Joan is represented as the agent of a transformation in the actual world ${ }^{65}$.

In the first scenes, Joan appeals to a doubter for the authority to lead the French troop to victory over the invading English. An apparent miracle at the close of scenes enables Joan to acquire authority over the feudal lords, the court, and the military. Her doubters interpret the nature of the miracle differently. Baudricourt in scene 1 and Charles in scene 2 are easily convinced of Joan's veracity. Shaw characterizes both as simple and foolish blowhards eager to entrust the fate of France to a supernatural power. Their simplicity and narrow- mindedness allow them to see divine inspiration in reason and coincidence. Dunois's reactions to Joan in scene 3 fall between the extremes of unquestioning faith and tempered disbelief. The stage directions describe him as "a good- natured and capable man who has no affectations and no foolish illusions". To this commander, who is her "comrade in arms", Joan's youth and innocence represent hope. On the riverbanks outside Orleans, Dunois asks Joan to pray for a west wind to carry his troop into the city, when the east wind suddenly changes at Joan's blessing, Dounis at once hands over to her the command of his army. In spite of this, he remains skeptical, and ever frightened of the reality of Joan's voices. He supports Joan as long as her advice is reasonable and brings success.

\footnotetext{
${ }^{64}$ David Daiches, A Critical History of English Literature.Vol.2,(London: Secker \& Warbury,1960), P 1108.

${ }^{65}$ Martz, P 162.
} 


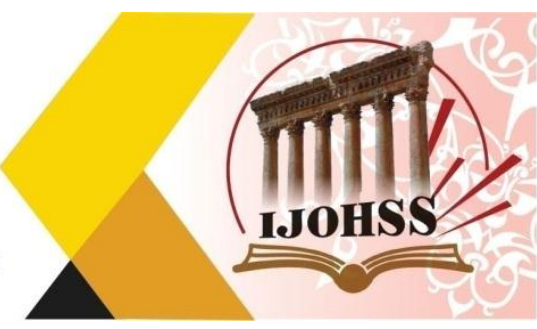

The discussion between Cauchon, Warwick and de Stogumber in scene 4 exemplifies the significance of the radical differences in what Joan's foes choose to believe. To the English clergy her military success and popularity represent witchery and sorcery. Chaplain de Stogumber's ignorance and simplicity cause him to fear what he cannot understand. He admits that she was inspired not from God but from Satan:

The Chaplain... I do not understand what your lordship means by protestant and Nationalist...I know as a matter of commonsense that the woman is a rebel; and that is enough for me. She rebels against Nature by wearing man's clothes, and fighting. She rebels against the Church by usurping the divine authority of the pope. She rebels against God by her damnable league with Satan and his evil spirits against our army. And all these rebellions are only excuses for her great rebellion against England... Let her perish. Let her burn66.

He felt that her rebellion would kindle many other revolutions because people began to trust her. So his solution to avoid any change that her revolution would make is to burn her. "Let her burn. Let her not infect the whole flock." ${ }^{54}$ For Warwick and Cauchon Joan is not a witch, but a heretic. They disagree, however, on the nature of her heresy. Warwick accuses her of a secular heresy that threatens the feudalistic order. By unifying the Burgundians, Bretons, Picards and Gascons as Frenchmen against Englishmen, she incites disobedience to the feudal lords. To Warwick she resembles a threat against the "whole social structure of Christendom" pays attention to Joan's nationalistic threat against the sovereignty of the Church. He fears that the division of God's kingdom into nations will dethrone Christ and thrust the world into chaos. The Inquisitor Lemaitre echoes Cauchon's abject fear of spiritual chaos at Joan's trial in Scene four. They describe her French nationalism and her disregard for the authority of the Church as signs of diabolical interference. This does not make her a witch as de Stogumber asserts, but a heretic. "All these things you [de Stogumber] call witchcraft are capable of a natural explanation. The woman's miracles would not impose on a rabbit: she does not claim them as miracles herself" ${ }^{68}$.Her crime then is not witchcraft, but pride. She sets her country above the

\footnotetext{
${ }^{66}$ Ibid, P 162.

${ }^{67}$ Shaw,Saint Joan:Selected Plays,ed.Dan H. Laurence(New York:Dodd,Mead \& Co.,1981),P 813.

${ }^{68}$ Ibid P 829.
} 


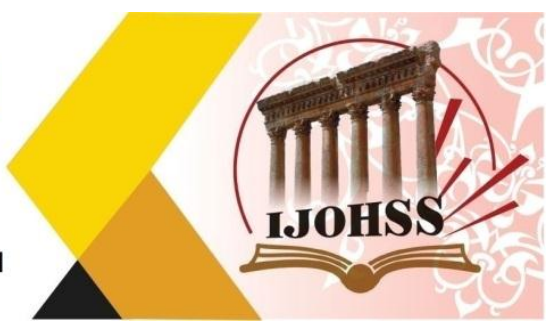

Holy Catholic Church and refuses the wisdom and sovereignty of God's anointed priests. All of them find excuses for burning her. She resembles the agent of transformation while they resemble the static cycle of life.

"The trial scene (vi) is the most romantic and emotional part of the play and it has done most to make Saint Joan popular"69 This scene presents Joan as a martyr. It shows the dramatic brilliance of Shaw. He made use of the records of the trial as a resource of the trial scene. It is an impressive scene. In it Shaw reflects how Joan bravely choose martyrdom and never fear from burning. "Shaw has invented an impressive human motive for Joan's ultimate decision: to die rather than surrender personal liberty, which is only another name for happiness" ${ }^{\text {"70 }}$. Shaw identifies Joan as a pioneer of change. Her ideas ushered in the age of Protestantism. She embodied the Renaissance spirit that was beginning to sweep Europe. In the Crucial moment before she was burnt at the stake, she faced death bravely and "death is transfigured into triumph by a soul made great, and refusal to surrender freedom of conscience becomes the jewel of her martyr's crown" $"$.

Shaw through the Epilogue considers this triumph of Saint Joan's martyrdom. Joan and her persecutors may not have been aware of the social and historical implications of their actions, but Shaw was. His carefully crafted narration of the events leading up to the trial and the comically ironic epilogue demonstrate the power of the evolutionary Life Force. The final scene or the Epilogue is as essential part of the play. Shaw's aim behind it is "to show that although Joan was killed and (as it seemed then) finally defeated, she was in truth victorious, not only because she helped in the liberation of France, but also because the ideas which centered in her went marching on through the centuries."72 The Epilogue is the product of Shaw's creative imagination and genius. It serves to show the victory of martyrdom of Saint Joan.

In the Epilogue the centuries run into each other in a series of dreams or visions in which all kinds of things can be introduced, however impossible they might seen in ordinary waking life. This scene is in some respects the best in the play. Shaw gets free from the confining framework of fact and becomes a genuine creator ${ }^{73}$.

69 Ibid P 829

${ }^{70}$ Ibid, P 827

${ }^{71}$ Ibid 823

${ }^{72}$ A. C. Ward,P 180.

${ }^{73}$ Avasthi and Maheshawari,P 109. 


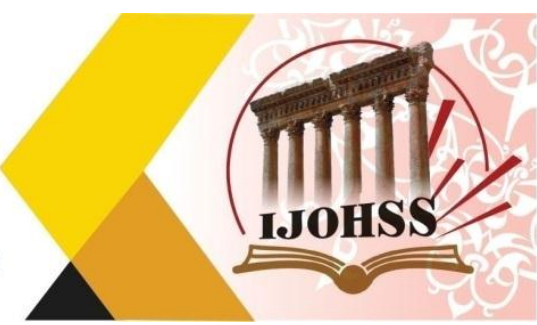

Even in the Epilogue, Shaw uses again the discussion between characters to evoke the ideas that cannot be narrated so easily. By letting, a martyr comes to the earthly life and talk to those who persecuted her, Shaw is able to show the reader what a martyr means. He lets us feel what a martyr has to say to his/ her killers. Being a martyr is a bless that saint Joan will own "nothing to any man", who in a way or another participated in making her a martyr by killing her. But she owes "everything to the spirit of God".

The use of irony in this scene is employed so as to let the reader think of the cruelty, old and new, that lets people slain others for only earthly interests. It lets us imagine "if she were able to come back amongst us none of us would be ready to receive her, we should all make excuses to carry on in the same old way"74. As mentioned earlier, Shaw wrote this play after the Roman Catholic Church had announced Joan of Arc's canonization in 1920. Perhaps Shaw's reply to this so late canonization, comes within the Epilogue and especially the laughter that satirically springs from the martyr and her killers: "A gentleman dressed in the fashion of the year 1920 suddenly appears before them. They all burst into uncontrollable laughter at his fancy dress. He has been sent to announce that Joan of Arc, having been admitted by the Church successively to the ranks of Venerable and blessed has now been called to the communion of the Church Triumphant as Saint Joan" "75. The laughter at this man symbolizes the answer to the hypocrisy of earthly institutions that once have condemned her and then, after centuries, and for political reasons, these same institutions considered her as saint. So in 1920 the heroine is as disillusioned as she was in 1431 and the curtain comes down on her cry of despair- "O God that madest this beautiful earth, when will it be ready to receive thy saints? How long? O Lord, how long?"76

\section{Fear As Reflected in Saint Joan}

In scene IV discussion between The chaplain and The Nobleman reveals key issue that is of nationalism. These two characters represent symbols . The Chaplain refers to religion and Church while The Nobleman refers to state authority. To them nationalism is a threat to their existence. Shaw also sheds the light on sectarianism as a tool to get rid of the nationals who revolt for the sake of their country. The fear from national revolution makes the authorities (represented by statemen,religious leaders ,or invaders) divide the nation so as to rule easily. The reformers' only way to defeat the tyranny is to unite the nation so as to triumph. Shaw reveals the fact that nationalism is the banner that embrace all different factions into one united army that

\footnotetext{
${ }^{74}$ Brodies Notes, $\mathrm{P} 27$.

75 A. C. Ward, P 181.

${ }^{76}$ Brodies Notes,P 27.
} 


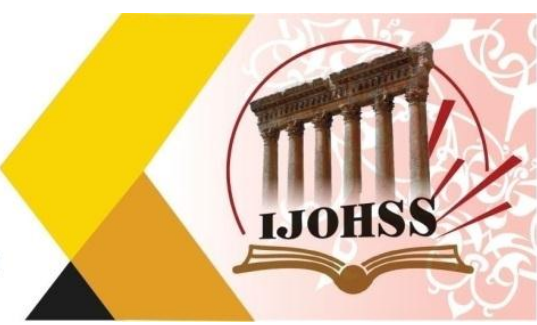

is undefeatable. A mechaism for defeating the national reformers is sectarianism.In the preceding dialogue, Shaw reflects how these forces divide and lable people into factions.Moreover,Shaw sheds the light on The Inquisition. Then through the dialogue between Cauchon and Warwick, another fear is described. It is the religious reforming. To them Saint Joan resembles a threat since she never mentions the church but "it is always God and herself." ${ }^{, 78}$ Cauchon compares her to prophet Mohammed:

Cauchon: A faithful daughter of The Church! The Pope himself at his proudest dare not to presume as this woman presumes. She acts as if she herself were The Church... She acts as if she herself were The Church... She sends letters to the king of England giving him God's command through her to return to his island on pain of God's vengeance. Let me tell you that the writing of such letters was the practice of the accursed Mohomet, the anti-Christ. ${ }^{79}$

To these Church men, Prophet Mohammed's message is also a threat. This is because his religion was spreading more and more everywhere. Consequently, their church is at risk:

Cauchon: ... by it an Arab camel driver drove Christ and His Church out of Jerusalem and ravaged his way west like a wild beast until at last there stood only the Pyrenees and God's mercy between France and damnation. Yet what did the camel driver do at the beginning more than this shepherd girl is doing? $\mathrm{He}$ had his voices from the angel Gabriel: she has her voices from the St. Catherine and St Margaret and the Blessed Michael. He declared himself the messenger of God ,and wrote in God's name to the kings of the earth. Her letters to them are going forth daily. ${ }^{80}$

This speech reveals the fear of Cauchon, who is an extremist Church man, from Islam. He fears from it for it spread so rapidly and also because it stir a trend of reforming among pious Christians. To Cauchon, Prophet Mohammed and the

\footnotetext{
${ }^{78}$ Ibid 102

${ }^{79}$ Ibid, P 102

${ }^{80}$ Ibid 103
} 


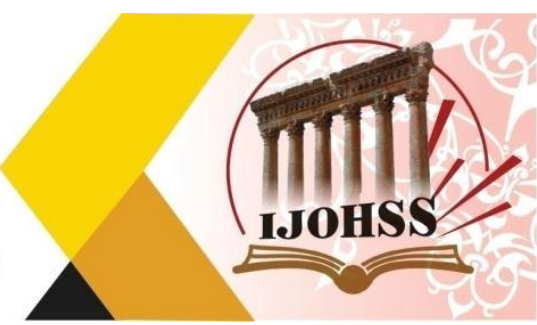

Christian reformists are only followers of Satan who "is spreading this heresy everywhere." 81 According to Cauchon these are heretics include Mohammed, Saint Joan and the following: The man Hus82,burnt only thirteen years ago at Constance ,infected all Bohemia with it. A man named Wcleef83, himself an anointed priest, spread the pestilence in England...We have such people here in France too: I know the breed ${ }^{84}$

The success of these reformers makes this man, Cauchon, feel afraid about his religious rank." It is cancerous: if it be not cut out, stamped out ,burnt out, it will not stop until it has brought the whole body of human society into sin and corruption, into waste and ruin," 85 says Cauchon justifying his fear from reformation. Shaw enters more deep inside the mind of this man revealing why he fears from Reformation:

\begin{abstract}
What will the world be like when the Church's
Accumulated wisdom and knowledge and experience, its councils of learned, venerable pious men, are thrust into the kennel by every ignorant laborer or dairymaid whom the devil can puff up with the monstrous selfconceit of being directly inspired from heaven ?It will be a world of blood, of fury, of devastation , of each man striving for his own hand: in the end a world wrecked back into barbarism... What will be when every girl thinks herself a Joan and every man a Mohomet? I shudder to the very marrow of my bones when I think of it. I have fought it all my life; and I will fight it to the end. ${ }^{86}$
\end{abstract}

81 ibid 103.

82 Bohemian reformer(1369-1416)who came under the influence of Wycliffe's writings. He was

Summoned to a General Church Council At Constance in 1414 to answer a charge of heresy and was given safe conduct, but the terms were violated and was seized and thrown into prison

After a travesty of a trial he was burnt at the stake in 1416.

${ }^{83}$ English reformer (1320-1384)whose teachings insisted that religion was an affair of the heart and not a matter of observance of routine Church ceremonies.His influence was widespread and, through persecution sei it back, continued strong until the reformation.

${ }^{84}$ Shaw,Saint Joan,P 103.

${ }^{85}$ Ibid, P 103.

${ }^{86}$ Ibid, P 103 


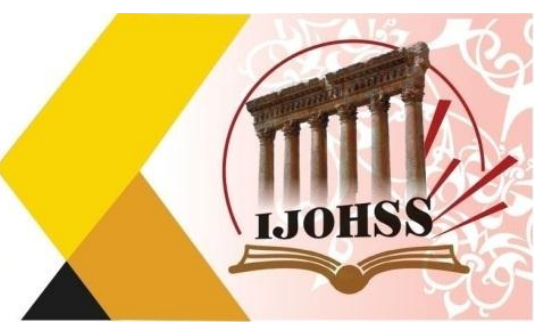

So this man is against reforming and change. Shaw describes the law of change as that of God. And those against change are against God. The church is thus is anti-God if it refuse change. Saint Joan or any reformers are agents of change, reform ,and progress that is necessary for the continuation of life. They are agents of the Life Force. They evolve upon the status of the hierarchy of state and church. this change revitalizes life and turns its cycle. Shaw affirms this fact in the Preface to Saint Joan as follows:

And as the law of God in any sense of the word which can now command a faith proof against science is a law of evolution, it follows that the law of God is a law of change, and when the Churches set themselves against change as such, they are setting themselves against the law of God ${ }^{87}$

The fear from such reforming change, makes persons, authorities, or ruling systems to stop it by any efficient aid. Shaw reflects in Saint Joan how this fear is working inside the minds of status rulers or religious leaders. Moreover, he shows why there was horrible acts and doctrines against reforming or revolution. The Inquisition Courts, as Shaw analyzes, was only a means to stop these reformations. Heresy was the normal accusation that is pasted on every reformer. Anyone adopting a belief against the church was considered a dissenter. And as a punishment for all these, they were burned .To those who sentenced such acts against reformers, "it is a painful duty" in comparison with "the horror of heresy "Their fear from reformation is transformed into a tool to terrify the nation as a whole. This tool was The Inquisition Courts with all its horrible acts.

The fear from Islam is intensified through this scene especially the conversation between Cauchon and Warwick. Shaw reveals through them how the western world instill a bad picture about Islam and the followers of prophet Mohammed. He also describes why the churchmen fears from Islam and Muslims:

Warwick: I am a soldier, not a churchman. As a pilgrim I saw something of the Mohametans. They we're not so ill- bred as I had been led to believe. In some respects their conduct compared favorably with ours.

\footnotetext{
${ }^{87}$ Shaw, "Preface”, Saint Joan,P37.
} 


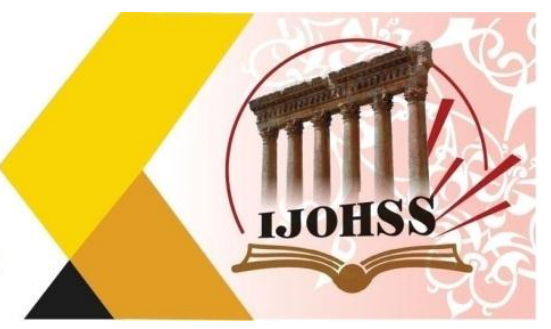

Cauchon(displeased)I have noticed this before. Men

them. go to the East to convert the infidels. And the infidels prevent

The crusader comes back more than half a Saracen. Not to mention that all Englishmen are born heretics .88

Thus revolutionaries and reformists were and still to be considered terrorist, for they terrify and threat the tyranny of status iniquity and injustice. No wonder Saint Jaon was considered a terrorist. Shaw in the Preface affirms this fact however:

\begin{abstract}
We must persecute, even to the death; and all we can do to mitigat the danger of persecution is, first, to be very careful what we persecute, and second ,to be bear in mind that unless there is a large liberty to shock conventional people, and a well-informed sense of the value of original individuality, and eccentricity, the result will be apparent stagnation covering a repression of evolutionary forces which will eventually explode with extravagant and probably destructive violence. $^{89}$
\end{abstract}

Shaw, in this passage, defines the horrible acts of the Inquisition Courts, or any behavior in any time, as "apparent stagnation covering a repression of evolutionary forces." So to overcome the fear from such agents of transformation and revolution, there exists the need to persecute, kill, burn, and to destruct all evolutionary forces. First, they will be accused of heresy or sometimes of terrorism. This is to minimizes their importance by deforming their reputation, and above all, so as not to patronize them. Second, they must be destructed for their mere existence is a threat .For this reason saint Joan was burnt. History narrates that thousands of martyrs were persecuted or burned for they bring new ideas or for they may revolt to reform. Shaw justifies this by saying "that all evolution in thought and conduct must at first appear as heresy and misconduct. If Joan was accused of heresy at her times, this still to occur in modern times but with some modifications. Joan of Arc is regarded by

\footnotetext{
${ }^{88}$ Ibid ,P 104.
} 


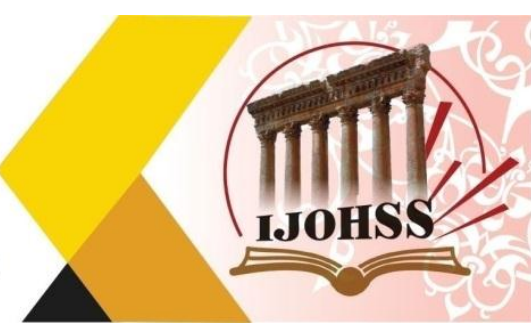

Bernard Shaw as a unique and revolutionary figure whose ideas match his philosophy of life.

\section{Works Cited}

1. Arnold, Joan, "Saint Joan of Arc ,A modern Day Hero For All ",www.stjoancentre.com

2. Adams ,William James, "France", Encarta Encyclopedia,Microsoft Corporation 2004.

3. Bently, Eric. Bernard Shaw. New York: New Directions, 1957.

4. Carrington ,Norman T. Brodie's Notes on Shaw's Saint Joan. London:Pan Book Ltd, 1976.

5. Colby Charles W.ed."Medieval Sourcebook: The Trial of Joan of Arc, 1431"Selections from the

6. sources of English History,55BC-AD 1832.London:Longman,Green,1920.

7. Daiches,David.A Critical History of English Literature.Vol.2, London: Secker \& Warbury, 1960.

8. Edward , Lucie Smith. "Joan of Arc" The Columbia Encyclopedia,6th edition,2001,www.bartleby.com/65/jo/joannabib.html.

9. Henneman ,Joan Bell, "Hundred Year's War", Encarta Encyclopedia,Microsoft corporation, 2004.

10. Kossuth , Louis, "Legends of Joan of Arc",www.thedividingnation.com/comlegends-of-JoanofArc.

11. Martz , Louis L. "The Saint as Tragic Hero", Tragic Themes in Western Literature, Cleanth Brook, ed. New Haven: Yale University Press, 1960.

12. Russell "Christopher. "The Creativity of Joan of Arc",www.therussell.net/papers/joan.

13. Roberts, Jeremy. Saint Joan of Arc .Minneapolis: Lerner Publication Co.2000.

14. Shaw. "Preface". Saint Joan, London: Penguin Books, 1961.

15. Shaw. Saint Joan,London:Longman, 1966.

16. Shaw, Saint Joan: Selected Plays, ed. Dan H. Laurence. New York: Dodd, Mead \& Co., 1981.

17. Valency, Maurice. The Cart and the Trumpet: The Plays of George Bernard Shaw. New York: Dodd, \& Co,1981.

18. Wilson, John Burgess. Survey of English Literature London: Longman, Green and Co Ltd,1969.

19. Weintraub Stanley ."George Bernard Shaw ”.Encarta Encyclopedia,Microsoft Corporation 2004.

20. www.joan-of-arc/joanofarc/biography.

21. www.joan-of-arc.org/joanofarc-footnote-113.html 